\title{
RELIGIOUS CONFLICTS: Opportunity Structures, Group Dynamics, and Framing
}

\author{
Tomas Lindgren \\ Umea University, Sweden \\ Email: tomas.lindgren@umu.se
}

\begin{abstract}
Explanations of violent religious conflicts usually focus on preconditions, facilitator causes or precipitating events at micro, meso or macro levels of analysis. As social psychology is the scientific study of the ways in which thoughts, feelings, perceptions, motives, and behaviors are influenced by interactions and transactions between groups and individuals, it can increase our understanding of the dynamics of religious conflicts at micro and meso levels. In this paper, I illustrate this point with a discussion of the utility of social movement theory for understanding the dynamics of religious conflicts. Social movement theory locates religious conflicts within broader contexts and complex processes by focusing on the interplay between micro and meso factors and the ways in which people perceive macro factors. Given certain conditions, religion can and often do contribute to collective violence. Religion is rarely, if ever, the main cause of intergroup conflicts, but is often used as an instrument for the mobilization of human and non-human resources. Appeal to religion may help conflicting parties overcome the collective action problem associated with intergroup conflicts. This does not necessarily mean that religious conflicts have unique characteristics or a logic of their own that sets them apart from other types of intergroup conflicts.
\end{abstract}

Keywords: Religion, conflict, violence, social psychology

\section{INTRODUCTION}

Religious conflicts are globally widespread and they tend to be more lethal, indiscriminate, and intractable than their secular counterparts (Fox, 2004; Pearce, 2005; Hassner, 2009; Toft, Philpott \& Shaw, 2011; Svensson, 2007; 2012; Svensson \& Nilsson, 2018; Isaacs, 2016; 2017). In the light of these findings, it is not surprising to find that the question of why people engage in religious conflicts have drawn attention from social scientists and scholars of religion. Several scholars argue that religion - or specific interpretations of religion - is a major cause of violence because it is absolutistic or particularistic (e.g., Hick, 1989; Kimball, 2002; Schwartz, 1997), irrational or non-rational (e.g., Appleby, 2000; Selengut, 2003; Jones, 2008), and/or divisive 
(e.g., Huntington, 1996; Avalos, 2005: Juergensmeyer, 2008; 2017). There are a number of problems with this conclusion (in addition to the difficulty in clearly distinguishing religious from non-religious motives), including the assumption that religious cognition has a direct impact on people's behavior, the de-contextualization of religion (or religious actors), and the reduction of the causes of conflicts into a single causal factor.

Studies on the link between religious beliefs and behavior are inconclusive, with some finding that religious beliefs have an impact on people's behavior while others have shown a lack of correspondence between religious beliefs and behavior (e.g., Wulff, 1997). An extensive body of empirical research demonstrates that religion's influence on behavior is more in the situation than in the person (e.g., Hood, Hill \& Spilka, 2009; Norenzayan, 2013). There are reasons to believe that religion encourages intergroup conflicts, but only under certain conditions. It is our job, I think, as social scientists and scholars of religion, to clarify the conditions under which religious beliefs promote intergroup conflicts (Lindgren, 2016).

Conflicts are interactive processes manifested in an actual or perceived incompatibility of goals between social entities, psychological processes, including cognitions, emotions, and motivations, and conflict behavior, such as the use of force to kill and injure the opponent, destruction of military or economic resources, verbal threats, and hostile gestures (Galtung, 1996). Religion can most certainly exert an influence on contradictions, beliefs, attitudes, feelings, motivations, and conflict behavior. But conflicts are by definition relational and the decision to resort to violence is usually a consequence of an escalation of a conflict, disillusionments with non-violent strategies, and/or a moral outrage at the opponent's aggression (Della Porta, 2013; Sageman, 2017). To understand why a religious group use violence we thus must take into account the political context of the conflict and the behavior of the opponent.

There is no doubt that religious beliefs have had an impact on several conflicts during the last four decades (Toft, Philpott \& Shaw, 2011). Absolutism, particularism or irrationality may have contributed to the conflicts, but they do not explain why conflicts have broken out between some religious groups but not between other religious groups, who also have absolutistic, particularistic or irrational beliefs. The root causes of intergroup conflicts are always multifaceted (Barash \& Webel, 2009). No single causal factor will therefore suffice to explain all or most cases of collective religious violence (Svensson, 2012). If a hypothesized causal factor, such as absolutism, particularism or irrationality, is present in at least two situations that occur under similar circumstances, and if the outcome is violence in 
one situation and nonviolence in the other, then under most circumstances that factor is not a primary cause of intergroup violence. It is thus important to examine religious conflicts that do not occur as well as those that do occur. Why have, for example, Protestants and Catholics in Northern Ireland been involved in violent conflicts, while Protestants and Catholics in South Africa and the Philippines have not been involved in such conflicts? Why do different religious groups sometimes live in peace for centuries and sometimes not?

Religious conflicts are often described as binary conflicts between unitary and bounded factions that are defined by the participants' religious identity, and the participants are often portrayed as being motivated by religious beliefs. But all such descriptions oversimplify the complexity of most religious conflicts as they usually entail a combination of identities, motives, and goals. Religious conflict parties are seldom, if ever, homogenous groups. In the religious war in Maluku (1999-2004), for example, the main conflicting parties were divided into several subgroups, such as Muslim vigilance groups and Christian vigilance groups, organized Muslim militias and organized Christian militias, and Muslim criminal gangs and Christian criminal gangs. The members of these groups, who were recruited from a wide spectrum of social categories, used violence to achieve multiple, overlapping, and sometimes mutually contradictory goals. During previous field research, I identified four ideal types of combatants in the war: "the ideologist" (people who were pulled into the war by their beliefs in the ideological cause), "the opportunist" (people who participated in the war in order to achieve social and/or economic gains), "the player" (people who were attracted by the adventure); and "the reluctant fighter" (people who were pushed into the war because they saw no other options) (Lindgren, 2014). Religious identity labels thus tend obscure the plurality of identities that exist within conflicting parties. Even if it could be demonstrated that a conflict group is religiously homogenous, it is not at all clear that religious beliefs are the reasons for their conflict behavior.

To be sure, religious beliefs might motivate action, but there are also other motivations that drive violent behavior, for example, the attraction of war, profit opportunities, and thrill (Mueller, 2007). Several studies suggest that religious beliefs are not among the most compelling motivations in the long run and in combat. More important is the social dynamic within the conflict unit, the ties among the soldiers, the loyalty to the brothers in arms, and the urge to contribute to the success of the group (e.g., Kalyvas, 2006).

Still, religion can and do exert an influence on violent conflicts, for example, by shaping and defining the conflicting parties that are engaged in fighting. It 
means in many cases that religion shapes people's identities and loyalties apart from its beliefs (Toft, 2007; Fox, 2000). Religions, like most ideologies, divide people into us and them. Before Christians and Muslims can fight, as they did in Maluku, they must believe themselves to be Christians and Muslims and not divide themselves into some other categories. Whenever a religious divide is used as the basis of mobilization, it requires the suppression of the human proclivity to see other people as both "with us" on some measures and "not with us" on other measures.

A vast body of research demonstrates that the mere identification with a social group tends to trigger in-group love and out-group hostility (e.g., Tajfel, 1970; Castano, Yzerbut, Bourguignon \& Seron, 2002; Halevy, Bornstein \& Sagiv, 2008). But to turn "them" into an "enemy", usually requires an additional component, such as grievances and a process of mobilization (Basedau, Pfeiffer \& Vüllers, 2016; Isaacs, 2016). To understand why people participate in religious conflicts we thus must demystify the conflicts by locating them within broader contexts and complex processes. The purpose of this paper is to discuss the utility of social movement theory for understanding the dynamics of religious conflicts.

\section{SOCIAL MOVEMENT THEORY}

Social movement theory is an integrative approach that focuses on the relationship between institutional political actors and various forms of political contention. The theory emphasizes the political context in which social movements and rebel groups emerge, the structures through which people and resources are mobilized, and collective representations of the social world. The theory has coalesced around three concepts: opportunity structures, mobilizing structures, and collective action frames (McAdam, 1999).

Opportunity structure, the first theoretical component of social movement theory, refers to external aspects of the political environment that constrain or empower collective actors, such as the degree of political openness and the presence or absence of support groups (Tarrow, 1988). This means that the opportunities to engage in successful collective action varies over time and that these variations can explain the ebb and flow of contentious politics (McAdam, 1999).

It is a psychological truism that we live in a perceived reality (Lindgren, $2005 ; 2014 b)$. Opportunities are subject to interpretation because no opportunity will invite to mobilization unless it is perceived as an opportunity. It is therefore important to pay attention to the interplay 
between structural conditions and subjective perceptions. Kurzman (1996) points out that there are sometimes mismatches between them such that people fail to perceive opportunities when they do exist, or perceive opportunities when they do not exist. Although there is no consensus on what constitutes a political opportunity structure, it is clear that contentious religious groups are shaped by the political context and often respond strategically to perceived opportunity structures. Social movement theorists recognize that political opportunities are insufficient to persuade people to participate in collective action. Mobilizing structures, the second component of social movement theory, refers to the networks through which the mobilization of resources, people, and collective action occurs. It is, in other words, those collective vehicles, informal networks as well as formal organizations, through which people mobilize and engage in collective action.

Social movement theorists also stress the importance of social networks. As a number of studies demonstrate, members of religious and political organizations are typically recruited through social networks. They seem to be particularly important in recruitment to high-risk activism (McAdam, 1986; Della Porta, 2013; Sageman, 2017). Della Porta (1988), for example, found that 70 percent of the members of militant left-wing groups in Italy joined while they had at least one close friend or kin involved in the group. In a study of rightwing terrorism in Italy, Weinberg and Eubank (1987) found that 60 percent of the activists had siblings in the movement, 18 percent had marital and 12 percent had parental relations with members of the radical right. In a study of global jihadism, Sageman $(2008,66)$ found that "about two thirds of the people in the sample were friends with other people who joined together or already had some connection to terrorism." Social networks can thus mold preferences before people decide to join a movement, socialize and build identities after they have been recruited, and offer participation opportunities to people who are sensitive to a particular issue (Passy, 2001). Social networks can also be an antidote to leaving a group and a support for sustained participation in collective actions (Della Porta \& Diani, 2006). Friendship is thus a key to recruitment as well a key to keeping group members.

Social movement theorists also stress the importance of formal organizations. The key challenge for social movement organizers is to create organizations that are sufficiently robust to structure contention, yet flexible enough to reach out to the social networks that link people to one another. Tarrow (2011) argues that the best way to address this challenge is through local organizations that are connected by social networks and coordinated by formal organizations. Local organizations can provide crucial resources to a social movement, such as 
members, leaders, communication networks, and enterprise tools (McAdam, 1999).

There is ample of evidence that social movements recruit participants most efficiently from existing organizations. It is a well-established fact that it is easier to recruit people with a shared sense of identity than to create new ones. Recruitment frequently occurs through "block recruitment" in which several or most members of an organization decide to join a social movement (Oberschall, 1973; McAdam, 1999). Social movements need leaders who "inspire commitment, mobilize resources, create and recognize opportunities, devise strategies, frame demands, and influence outcomes (Morris \& Staggenborg, 2004, 171)." Sometimes leaders produce social movements and sometimes social movements produceleaders out of the struggle or from existing organizations. Finally, established organizations may provide communication infrastructures, practical tools and services, such as meeting places, office supplies, and lawyers (McAdam, 1999). But for the aggrieved to participate in collective action, there must first be a cognitive liberation or an insurgent consciousness, that is, "a collective state of understanding which recognizes that social change is both imperative and viable (Smith, 1991, 62)."

Collective action is not only constructed out of organizations, but also out of shared understandings that justify, dignify, and animate collective action. The third component of social movement theory is collective action frames. The term "frame" refers to "an interpretive schemata that simplifies and condenses the world out there' by selectively punctuating and encoding objects, situations, events, experiences, and sequences of actions within one's present or past environment. [...] Collective action frames not only perform this focusing and punctuating role; they also function simultaneously as modes of attribution and articulation (Snow \& Benford, 1992, 137)." Thus, collective action frames define a social situation as a problem, including attributions of responsibility and targets of blame, articulate a proposed solution to the problem, devise strategies for addressing the problem, and offer a rational for engaging in collective action.

Collective action frames are generated by an interactive, discursive process which involve a "connection and alignment of events and experiences so that they hang together in a relatively unified and compelling fashion," and "accenting and highlighting some issues, events, or beliefs as being more salient than others (Benford \& Snow, 2000, 623).” The framing process always occurs in a context in which various actors, such as social movement organizers, participants, authorities, media, and counter-movements, are engaged in intragroup/movement framing disputes and intergroup/movement 
counterframing/framing contests. Framing is a strategic process that aims to achieve a specific goal: recruitment of participants, economic resources, and so forth. In order to achieve the goal, a frame must resonate with potential participants and the wider cultural context in which a movement operates. Social movement scholars have demonstrated that resonance is related to cultural sensitivity, credibility and salience (Williams, 2004).

The process through which social movements link their interpretative frameworks with people's values and goals is called frame alignment, of which there are four types: frame bridging, frame amplification, frame extension, and frame transformation. Frame bridging is linking ideologically congruent but structurally unconnected frames. Frame amplification refers to a clarification, elaboration or revitalization of cultural beliefs or values that relate to a specific issue. Frame extension is to extend an interpretive frame to include issues and concerns that are secondary to the movement's primary goals but are of importance to a target population. Frame transformation, which is the most ambitious strategy, refers to a reformulation of a collective action frame or a formation of a new one (Snow, Rochford, Worden \& Benford, 1986).

Frame alignment processes thus serve to link a movement's activities and goals with a target of mobilization. Sometimes frames originate from ideologies and sometimes ideologies are influenced by frames. Although frames usually do not consist of a systematic body of ideas and ideals, some provide a more comprehensive understanding of the social world. This is particularly true of master frames, that is, "collective action frames that have expanded in scope and influence such that they color and constrain the orientations and activities of other movements (Snow, 2004, 390)." Master frames that are broad in interpretive scope, such as global justice, war on Islam, and antiimperialism, allow "numerous aggrieved groups to tap it and elaborate their grievances in terms of its basic problem-solving schema (Snow \& Benford, 1992, 140)."

\section{MOBILIZATION FOR RELIGIOUS CONFLICTS}

Religious conflicts are willed actions and leaders usually play critical roles in instigating collective violence (Brass, 2003). They normally exploit popular grievances for economic, political or ideological gains. Some leaders thus mobilize along identity lines in order to advance their political or economic interests via conflicts, others mobilize along identity lines in order to advance their religious interests via conflicts (Barter \& Zatkin-Osburn, 2014). In both cases, the leaders must perceive a political opportunity and 
mobilize human and non-human resources before they can engage in violent conflicts. Mobilization is facilitated when the leader is imbued with moral authority and embody the in-group identity. Successful leaders typically stand for the group, stand up for the group, craft a sense of us, and make the group members matter (Glenny, 1999; Haslam, Reicher \& Platow, 2011).

Control over national mass media can have tremendous effects on conflict mobilization. If a conflict group can convey their action frames to millions of people, encouraging some to join them and others to take note of their claims, it becomes possible to create a large movement without incurring the costs of building and maintaining a mass organization. The importance of controlling mass media outlets has been observed in several conflict areas, for example, in Serbia prior to the wars against Croatia and Bosnia (Mueller 2000). Mass media can thus be used to win the hearts and minds of activists, supporters, and sympathizers. The use of religious rhetoric and symbolism can provide access to religious media channels. In Maluku, for example, both sides used religious mass media in order to mobilize human and non-human resources (Hasan, 2006; Lindgren, 2014).

Social media has changed the nature of religious conflict in many ways. It has, for example, extended the range of social networks internationally and diminished the importance of local organizations as bases for mobilization. Social media has made it possible for conflict groups to bypass government censorship and the filters of established media outlets, and communicate directly with members, sympathizers, supporters, enemies, and other political actors. Most conflict groups today use various network platforms to disseminate information and propaganda, mobilize non-human resources, and recruit participants, sympathizers, and supporters. Armed conflicts require material resources, such as money, weapons, ammunition and technology. Some of the most common sources of funding are robbery, taxation of the local population, and donations from external support groups. Appeal to religion can facilitate mobilization of external support because people tend to support their coreligionists when they are in trouble (Fox, 2002; Lindgren, 2014).

Conflict groups need organizations and social networks in order to participate successfully in collective violence. Conflict leaders must either create new organizations or transform existing ones into conflict organizations. To frame a conflict in religious terms may provide access to organizational resources. Religious organizations were turned into conflict organizations in several conflicts during the last four decades. In Maluku, for example, both sides had established headquarters in Kota Ambon, the capital of the province of Maluku. The Christian headquarter, which was located in the 
Maranatha Church, served as a communication and crisis center. The church provided a network connecting Christian communities across the province, which facilitated the recruitment of combatants and the coordination of Christian troops. The Muslims had their headquarters in the Al Fatah Mosque, a stone's throw from the Maranatha church. From there, the armed struggle was organized under the auspices of retired military personnel. The Mosque also served as a communication center, hospital and a safe haven for refugees (Van Klinken, 2007). Homeless people lived more or less permanently in the churches and the mosques during the conflict, and the mere sight of the refugees strengthened the morale on both sides (Lindgren, 2014).

Armed conflicts require, of course, a large number of dedicated fighters. For conflict groups, itisimportanttoidentifypeoplewhoarewillingtomakegreat sacrifices for long-term goals. To recruit people who are not sufficiently motivated often leads to problems as they tend to expect more short-term rewards than more motivated soldiers (Weinstein, 2005). There is ample of evidence that young men tend to be more motivated to participate in intergroup violence than any other demographic group (e.g., Mesquida \& Wiener, 1996; 1999; Reedy-Maschner \& Maschner, 1999). Recruitment for an armed conflict thus does not require a large population base but a pool of young males, which many religious organizations can provide through "block recruitment". It is therefore hardly surprising that leaders typically address young males in their recruitment campaigns, and that many religious conflict groups are dominated by males under the age of 30 (e.g., Bose, 2003; Brass, 2003; McKenna, 1998).

To mobilize successfully, leaders must effectively manage two processes: consensus mobilization and action mobilization (Klandermans, 1984). Consensus mobilization is the process through which a conflict organizer attempts to convince people that a violent conflict is necessary and justified. Conflict groups promote such interpretations by disseminating collective action frames. As I said above, collective action frames are perceived more positively if they resonate with people's beliefs and values and the wider cultural context in which a conflict group operates. Incorporation of religious concepts, symbols, and metaphors into collective action frames is often a part of alignment processes. They can justify the cause, which bring hope in times of misery and purpose in times of despair, and they can help to dehumanize the enemy, which makes it easier to kill them.

Action mobilization is the process through which a conflict organizer attempts to motivate people to participate in a religious conflict. It includes promoting sympathy for the cause among the population, targeting sympathizers within the population, motivating the sympathizers, and 
persuading them to participate in the conflict. Sympathy, which is typically the result of consensus mobilization, is based on people's identification with a conflict group. Identification is cheap and most people who identify with a cause tend to remain passive sympathizers. Leaders often target and motivate sympathizers by using kinship terms in the mobilizing rhetoric, such as "brother" and "sister". It was used by both factions during the religious conflict in Maluku. For example, Jafar Umar Thalib, the commander of Laskar Jihad, emphasized in the declaration of war that it was a religious duty for all Muslims to take up arms to defend their "brothers in faith":

What law in this world can oppose Allah's law when Allah states that we are obliged to fight to defend the oppressed people who cannot defend themselves? And what earthly law can prohibit the religious obligation expressed in the command of Allah, "And if they, your brothers in faith, ask you for your help, then you are ordained to help them." Therefore, I state emphatically that all laws and regulations that oppose Allah's commandments are actually invalid (Lindgren, 2014).

To induce a feeling of fictive kinship reduces the social complexity within the conflict group, strengthen the ties between the group members, and reinforce the differences between the conflicting parties.

Another way to motivate people is to evoke people's anger by focusing on the victimization of in-group members in the rhetoric. Most conflict groups, like the conflicting parties in Maluku, are built around a deliberate cultivation of anger or hatred. It is well-known that inducement of anger is an effective way to overcome fear, which tend to de-activate collective action. When the individual overcomes fear, positive emotions often take over, such as enthusiasm, which can generate a hope that risky behaviors will have positive outcomes (Huddy, Feldman \& Cassese, 2007). Conflict groups need motivated people who are willing to expose themselves to great risks. Religions can be important in this regard when they justify the cause and promise heavenly rewards to those who die in battle. Religious beliefs and practices may strengthen the solidarity with the conflict, and help to overcome the collective action problem. Members of conflict groups must trust each other. Religion can build trust by demanding hard to fake rituals that signals commitment to the group (Sosis, Kress \& Boster, 2007), and the activation of god concepts can help conflict groups to solve freerider problems (Johnson, 2016). It is thus strategic to refer to religion in the mobilizing rhetoric. 


\section{CONCLUSION}

In this paper, I have reviewed some of the core concepts of social movement theory that can - and do - contribute to a contextual understanding of religious conflicts. The social movement theory framework locates religious conflicts within broader contexts and complex processes by focusing on the interplay between micro and meso factors and the ways in which people perceive macro factors, such as economic inequality, state repression and political exclusion. Adoption of such a framework can reveal how beliefs change as a consequence of participation in group dynamics. I suggest that the power of religion lies primarily in its mobilizing potential. Religious conflicts are elite-driven processes. Conflict organizers use religious concepts and symbols because they are efficient tools to mobilize human and nonhuman resources. And some aspects of religion may help conflicting parties overcome the collective action problem associated with intergroup violence, including the human tendency to free- ride and to leave the fighting to others. Thus, religion is as much a consequence as a cause of intergroup conflicts.

\section{BIBLIOGRAPHY}

Appleby, R. S. (2000). The ambivalence of the sacred: Religion, violence, and reconciliation. Lanham, MD: Rowman \& Littlefield.

Avalos, H. (2005). Fighting words: The origins of religious violence. Amherst, NY: Prometheus Books.

Barash, D. P. \& Webel, C. P. (2009). Peace and conflict studies (second edition). Thousand Oaks, CA: SAGE.

Barter, S., \& Zatkin-Osburn, I. (2014). Shrouded: Islam, war, and holy war in Southeast Asia. Journal for the Scientific Study of Religion, 53, 187-201.

Basedau, M., Pfeiffer, B., \& Vüllers, J. (2016). Bad religion? Collective action, and the onset of armed conflict in developing countries. Journal of Conflict Resolution, 60, 226-255.

Benford, R. D., \& Snow, D. A. (2000). Framing processes and social movements: An overview and assessment. Annual Review of Sociology, 26, 611-639.

Bose, S. (2003). Kashmir: Roots of conflict, paths to peace. Cambridge, MA: Harvard University Press.

Brass, P. R. (2003). The Production of Hindu-Muslim Violence in Con- 
temporary India. Seattle, WA: University of Washington Press.

Castano, E., Yzerbut, V., Bourguignon, D., \& Seron, E. (2002). Who may enter? The impact of in-group identification on in-group/out-group categorization. Journal of Experimental Social Psychology, 38, 315- 322.

Della Porta, D. (1988). Recruitment processes in clandestine political organizations: Italian left-wing terrorism. International Social Movement Research, 1, 155-169.

Della Porta, D. (2013). Clandestine political violence. Cambridge, UK: Cambridge University Press.

Della Porta, D., \& Diani, M. (2006). Social movements: An introduction (second edition). Malden, MA: Blackwell.

Fox, J. (2000). Is Islam more conflict prone than other religions? A cross- sectional study of ethnoreligious conflict. Nationalism and Ethnic Politics, 6, 1-24.

Fox, J. (2002). Ethnoreligious conflict in the late twentieth century: A generaltheory. Lanham, MD: Lexington Books.

Fox, 3. (2004). Religion, civilization, and civil war: 1945 through the millennium. Lanham, MD: Lexington Books.

Galtung, 3. (1996). Peace by peaceful means: Peace and conflict, development and civilization. London: SAGE.

Glenny, M. (1999). The Balkans: Nationalism, war, and the great powers, 1840-1999. New York: Penguin.

Haslam, A. A., Reicher, S. D., \& Platow, M. 3. (2011). The New psychology ofleadership: Identity, influence and power. New York: Psychology Press.

Halevy, N., Bornstein, G., \& Sagiv, L. (2008). "In-group love" and "out- group hate" as motives for individual participation in intergroup conflict: A new game paradigm. Psychological Science, 19, 405-4 11.

Hasan, N. (2006). Laskar Jihad: Islam, militancy, and the quest for identity in postNew Order Indonesia. Ithaca, NY: Cornell Southeast Asia Program.

Hassner, R. (2009). War on sacred grounds. Ithaca, NY: Cornell University Press.

Hick, J. (1989). An interpretation of religion. London: Macmillan.

Hood, R. W. Jr., Hill, P. C., \& Spilka, B. (2009). The psychology of religion: An empirical approach (fourth edition). New York: The Guilford Press.

Huddy, L., Feldman, S., \& Cassese, E. (2007). On the distinct political effects of anxiety and anger. In W. R. Neuman, G. M. Marcus, A. N. 
Crigler \& M. Mackuen (Eds.), The affect effect: Dynamics of emotion in political thinking and behavior (pp. 202-230). Chicago: The University of Chicago Press.

Huntington, S. (1996). The clash of civilizations and the remaking of the world order. New York: Simon \& Schuster.

Isaacs, M. (2016). Sacred violence or strategic faith? Disentangling the relationship between religion and violence in armed conflict. Journal of Peace Research, 5, 2 11-225.

Isaacs, M. (2017). Faith in contention: Explaining the salience of religion in ethnic conflict. Comparative Political Studies, 50, 200-23 1.

Johnson, D. (2016). God is watching you: How the fear of God makes us human. New York: Oxford University Press.

Jones, J. (2008). Blood that cries out from the earth: The psychology of religious terrorism. New York: Oxford University Press.

Juergensmeyer, M. (2008). Global rebellion: Religious challenges to the secular state, from Christian militias to al Qaeda. Berkeley, CA: University of California Press.

Juergensmeyer, M. (2017). Terror in the mind of God: The global rise of religious violence (fourth edition, revised and updated). Berkeley, CA: University of California Press.

Kalyvas, S. N. (2006). The logic of violence in civil war. Cambridge, UK: Cambridge University Press.

Kimball, C. (2002). When religion becomes evil. San Francisco: HarperCollins.

Klandermans, B. (1984). Mobilization and participation: Social psychological expansions of resource mobilization theory. American Sociological Review, $49,583-600$.

Kurzman, C. (1996). Structural opportunity and perceived opportunity in social movement theory: The Iranian revolution of 1979. American Sociological Review, 61, 153-170.

Lindgren, T. (2005). The narrative construction of Muslim prayer experiences. International Journal for the Psychology of Religion, 2, 159174.

(2014). Religion och konflikt [Religion and conflict]. Skellefteå, Sweden: Artos bokförlag. 
--------, (2014b). Hjalmar Sundén's impact on the study of religion in the Nordic countries. Temenos, 52, 39-61.

-------, (2016). The psychological study of religious violence: A theoretical and methodological study. Al-A lbab, 5, 155-174.

McAdam, D. (1986). Recruitment to high-risk activism: The case of freedom summer. American Journal of Sociology, 92, 64-90.

McAdam, D. (1999). Political process and the development of black insurgency, 1930-1970 (second edition). Chicago: The University of Chicago Press.

McKenna, T. M. (1998). Muslim rulers and rebels: Everyday politics and armed separatism in the southern Philippines. Berkeley, CA: University of California Press.

Mesquida, C. G. \& Wiener, N. I. (1996). Human collective aggression: A behavioral ecology perspective. Ethology and Sociobiology, 17, 247- 262.

Mesquida, C. G. \& Wiener, N. I. (1999). Male age composition and the severity of conflicts. Politics and the Life Sciences, 18, 18 1-189.

Morris, A., \& Staggenborg, S. (2004). Leadership in social movements. In D. Snow, S. Soule \& H. Kriesi (Eds.), The Blackwell companion to social movements (pp. 17 1-196). Oxford, UK: Blackwell.

Mueller, J. (2000). The banality of ethnic war . International Security, 1,2-70.

, (2007). The remnants of war. Ithaca, NY: Cornell University Press.

Norenzayan, A. (2013). Biggods: How religion transformed cooperation and conflict. Princeton, NJ: Princeton University Press.

Oberschall, A. (1973). Social conflict and social movements. Englewood Cliffs, NJ: Prentice-Hall.

Passy, F. (2001). Socialization, connection, and the structure/agency gap: A specification of the impact of networks on participation in social movements. Mobilization: An International Journal, 6, 173-192.

Pearce, S. (2005). Religious rage: A quantitative analysis of the intensity of religious conflicts. Terrorism and Political Violence, 17, 333-352.

Reedy-Maschner, K. L. \& Maschner, H. D. G. (1999). Marauding middlemen: Western expansion and violent conflict in the subarctic. Ethnohistory, 4, 703-743.

Sageman, M. (2008). Leaderlessjihad: Terror networks in the twenty-first century. Philadelphia: University of Pennsylvania Press. 
Sageman, M. (2017). Turning to political violence: The emergence of terrorism. Philadelphia: University of Pennsylvania Press.

Schwartz, R. M. (1997). The curse of Cain: The violent legacy of monotheism. Chicago: University of Chicago press.

Sosis, R., Kress, H., \& Boster, J. (2007). Scars for war: Evaluating alternative signaling explanations for cross-cultural variance in ritual costs. Evolution and Human Behavior, 28, 234-247.

Selengut, C. (2003). Sacred fury: Understanding religious violence. Walnut Creek, CA: AltaMira.

Smith, C. (1991). The emergence of liberation theology: Radical religion and social movement theory. Chicago: The University of Chicago Press.

Snow, D. A. (2004). Framing processes, ideology, and discursive fields. In D. Snow, S. Soule \& H. Kriesi (Eds.), The Blackwell companion to social movements (pp. 380-412). Oxford, UK: Blackwell.

Snow, D. A., \& Benford, R. D. (1992). Master frames and cycles of protest. In A. Morris \& C. M. Mueller (Eds.), Frontiers in social movements (pp. 133-155). New Haven, CT: Yale University Press.

Snow, D. A., Rochford, B. E., Worden, S., \& Benford, R. D. (1986). Frame alignment processes, micromobilization, and movement participation. American Sociological Review, 51, 468-481.

Svensson, I. (2007). Fighting with faith: Religion and conflict resolution in civil wars. Journal of Conflict Resolution, 51, 930-949.

--------, (2012). Ending holy wars: Religion and conflict resolution in civil wars. St Lucia, New Zeeland: University of Queensland Press.

Svensson, I., \& Nilsson, D. (2018). Disputes over the divine: Introducing the religion and armed conflict (RELAC) data, 1975 to 2015. Journal of Conflict Resolution, 62, 1127-1148.

Tajfel, H. (1970). Experiments in intergroup discrimination. Scientific American, 223, 96-102.

Tarrow, S. (1988). National politics and collective action: Recent theory and research in Western Europe and the United States. American Review of Sociology, 14, 42 1-440.

, (2011). Power in movement: Social movements and contentious politics (revised and updated third edition). Cambridge, UK: Cambridge University Press. 
------, (2006). Issue indivisibility and time horizons as rationalist explanations for war. Security Studies, 1, 34-69.

Toft, M. D. (2007). Getting religion? The puzzling case of Islam and civil war. International Security, 4, 97-13 1.

Toft, M. D., Philpot, D., \& Shah, T. S. (2011). God's century: Resurgent religion and global politics. New York: W. W. Norton \& Company.

Van Klinken, G. (2007). Communal violence and democratization in Indonesia: Small town wars. London: Routledge.

Weinberg, L., \& Eubank, W.L. (1987). The rise and fall of Italian terrorism. Boulder, CO: Westview Press.

Weinstein, J. M. (2005). Resources and the information problem in rebel recruitment. Journal of Conflict Resolution, 49, 600-624.

Williams, R. H. (2004). The cultural contexts of collective action. In D. Snow, S. Soule \& H. Kriesi (Eds.), The Blackwell companion to social movements (pp.91-115). Oxford, UK: Blackwell.

Wulff, D. M. (1997). Psychology of Religion: Classic and contemporary (second edition). New York: John Wiley \& Sons. 